ACTA UNIVERSITATIS WRATISLAVIENSIS

No 3779

Studia nad Autorytaryzmem i Totalitaryzmem 39, nr 1

Wrocław 2017

DOI: $10.19195 / 2300-7249.39 .1 .1$

ROMAN BÄCKER

Uniwersytet Mikołaja Kopernika w Toruniu

\title{
Totalitaryzm w cywilizacji informatycznej
}

Rozważania nad totalitaryzmem posiadają ogromną historię, którą bardzo wyraźnie należy rozdzielić na dwa nurty.

Pierwszy z nich należy do Paretowskich derywacji, choć funkcjonuje nie tylko w publicystyce czy wystąpieniach publicznych. W tym sposobie myślenia totalitarnym jawi się wszystko, co według danego autora mieści się pomiędzy postrzeganym przez niego jako skrajne, absolutne zło a niezgadzaniem się z jego poglądami bądź działaniami. Ta skrajność może być bardzo łatwo ilustrowana publicystyką komunistów z lat 30. XX w. (zresztą późniejszą również), oskarżających o faszyzm (faszyzm katolicki, socjalfaszyzm itd.) wszystkich tych, którzy się z nimi nie zgadzali lub nie chcieli się w pełni podporządkować. Wartym odnotowania współczesnym przykładem utożsamiania przeciwnika ze skrajnym złem jest wzajemne oskarżanie się przynajmniej o tendencje totalitarne polityków Prawa i Sprawiedliwości oraz Platformy Obywatelskiej ${ }^{1}$.

Natomiast drugi nurt cechuje się (w mniejszym lub większym stopniu) dążeniem do prawdy. Można do niego włączyć wszelkie usiłowania intelektualne, w których zmierza się do ustalenia obiektywnych kryteriów ściśle odróżniających reżim totalitarny od innych. Począwszy od pierwszych, bardzo ciekawych zresztą i często intuicyjnych, usiłowań autorów międzywojennych ${ }^{2}$, poprzez fundamentalne i porządkujące teksty powojenne (Hannah $\mathrm{Arendt}^{3}$, Carl Friedrich wraz ze Zbigniewem Brzezińskim ${ }^{4}$ ) oraz nowatorskie opracowania $\mathrm{z}$ lat

1 -, Schetyna ostrzega przed państwem totalitarnym PiS: „, Państwo staje się totalne”, 27.11.2015, http://natemat.pl/163323, schetyna-panstwo-staje-sie-totalne-a-to-krok-od-panstwa-totalitarnego (dostęp: 4.05.2017); - , Platforma pelzajacego totalitaryzmu. Platforma Podstuchu. Platforma bez żartów, 21.01.2013, http:/wpolityce.pl/polityka/149089-platforma-pelzajacego-totalitaryzmu-platforma-podslu chu-platforma-bez-zartow (dostęp: 4.05.2017).

2 Zob. np. M. Kornat, Bolszewizm, totalitaryzm, rewolucja. Rosja: poczatki sowietologii i studiów nad systemami totalitarnymi w Polsce (1918-1939), Kraków 2004.

${ }^{3}$ H. Arendt, The Origins of Totalitarianism, Orlando-New York-London 1973.

4 C.J. Friedrich, Z.K. Brzeziński, Totalitarian Dictatorship, Cambridge 1965. 
70. XX w. (Juan Linz ${ }^{5}$, Alain Besançon ${ }^{6}$ ), a na współczesnych (często kazualnych) kończąc, zgromadziła się ogromna literatura, notabene warta historiograficznego opracowania ${ }^{7}$.

Podobny charakter mają osiągnięcia polskiej literatury naukowej zajmującej się problematyką reżimów niedemokratycznych, a szczególnie totalitaryzmu. Konieczne jest jednak zaznaczenie poważnej różnicy. O ile w okresie międzywojennym poziom polskiej literatury naukowej nie odbiegał od światowej, inaczej było w okresie powojennym. Znaczące teksty można odnaleźć głównie na emigracji, aczkolwiek miały one raczej charakter literacki (zob. powieści Czesława Miłosza) niż obiektywizującej refleksji prawdoupodabniającej (warto w tym kontekście wymienić przede wszystkim dzieło Leszka Kołakowskiego Główne nurty marksizmu ${ }^{8}$ ). Sytuacja się zmienia w latach 80 . XX w. — pojawienie się literatury bezdebitowej i jej rozpowszechnienie na skalę masową, ale przede wszystkim swobodna wymiana myśli naukowej w ramach nie tylko „oralnej socjologii”, lecz także wszelkich nauk społecznych pozwoliło na powstanie wielu ważnych tekstów dotyczących reżimów totalitarnych. Wśród nich można wymienić teksty m.in. Andrzeja Walickiego ${ }^{10}$ oraz Marii Zmierczak ${ }^{11}$.

Charakterystycznym zjawiskiem dla okresu po rozpadzie imperium sowieckiego oraz znaczących przemian w wielu krajach komunistycznych jest zmniejszenie się poziomu zainteresowań naukowych totalitaryzmem. Staje się on w coraz większym stopniu domeną badawczą historyków, w coraz mniejszym zaś - politologów i prawników.

Tymczasem powstaje coraz więcej prac socjologów i makroekonomistów, ale też politologów, poświęconych analizie konsekwencji społecznych wielu gwałtownie przebiegających współzależnych procesów świadczących o rewolucyjnym procesie przekształceń ludzkości ze stanu industrialnego czy postindustrialnego w świat informatyczny, sieciowy, cyfrowy itd.

Procesy nagłej jedno- i dwupokoleniowej deterytorializacyjnej globalizacji w warunkach kurczącego się czasu są jednocześnie połączone z innymi zjawiskami.

5 J.J. Linz, Totalitarian and Authoritarian Regimes, Reading 1985; zob. szczególnie bardzo inspirujące: idem, Totalitarianism and Authoritarianism, [w:] The Handbook of Political Science, red. F.I. Greenstein, N.W. Polsby, t. 3. Macropolitical Theory, Reading 1975, s. 336-350.

6 A. Besançon, Les origines intellectuelles du léninisme, Calmann-Lévy 1994.

${ }^{7}$ Monografia Eckharda Jessego ma charakter już w dużej mierze historyczny. Zob. E. Jesse, Totalitarismus im 20. Jahrhundert. Eine Bilanz der internationalen Forschung, Bonn 1996.

8 L. Kołakowski, Main Currents of Marxism, Oxford 1978.

9 Zob. A. Sułek, Przeciwko socjologii oralnej, „Kultura i Społeczeństwo” 31, 1987, nr 4, s. 227-229.

${ }^{10}$ A. Walicki, Marksizm i skok do królestwa wolności: dzieje komunistycznej utopii, Warszawa 1996.

11 M. Zmierczak, Spory o istotę faszyzmu: dzieje i krytyka, Poznań 1988; eadem, Jan Jakub Rousseau - rzecznik totalitaryzmu czy liberalnej demokracji?, „Czasopismo Prawno-Historyczne” 41, 1989, nr 2, s. 1-16; eadem, Własność w ideologii narodowych socjalistów, „Czasopismo Prawno-Historyczne" 56, 2004, nr 2, s. 271-281. 
W sposób raptowny zanikają nie tylko wiązki tradycyjnych zawodów, lecz także błyskawicznie zmniejszają się całe grupy społeczno-zawodowe oraz klasy społeczne. Cykliczne, kołowe rozumienie czasu - typowe dla struktur agrarnych — wraz z etosem punktualności, czasem mierzalnym (od - do) - charakterystycznym dla industrialnej pracy zespołowej — tracą dominację na rzecz deadline' $u$ - czasu do pewnej granicy. Życie nie tylko gospodarcze, ale również społeczne nie toczy się nieprzerwanie, ale jest organizowane od projektu do projektu, od zadania do zadania. O ile poprzednio role społeczne były ściśle zdefiniowane, o tyle w świecie internetowym mogą być nadawane na użytek danej sytuacji i jednocześnie można pełnić kilka takich samych ról społecznych, przy czym każda z nich jest inaczej zdefiniowana. W dodatku następuje znaczące wymieszanie tradycyjnych ról społecznych. Konsument staje się producentem nie tylko w ramach procesów makdonaldyzacji ${ }^{12}$. Googlizacja jest etapem wyższym - procesem automatycznego generowania funkcji producenckich, konsumenckich i marketingowych ${ }^{13}$. Postnowoczesność jest zarówno płynna, jak i nieprzewidywalnie zmienna.

Przejście do cywilizacji informatycznej jest procesem niesłychanie szybkim, całkowicie przekształcającym nie tylko całe otoczenie społeczne, lecz także samego człowieka. Jest to rewolucja taka sama, jak agrarna czy industrialna, ale zachodząca - nawet w porównaniu z tą ostatnią — o wiele szybciej i o wiele gwałtowniej, opanowując wszystkie możliwe dziedziny życia społecznego i osobistego.

Jednocześnie pod względem struktur politycznych mamy do czynienia ze zjawiskiem o charakterze nakładkowym, a nie destrukcyjno-kreatorskim. W dalszym ciągu funkcjonują dotychczasowe formy, mechanizmy i instytucje życia politycznego, przy czym jednym z warunków powodzenia dla aktorów politycznych staje się umiejętne wykorzystywanie nowych technologii komunikacji politycznej. Jest to zbieżne ze sposobem funkcjonowania globalnej gospodarki informatycznej, która funkcjonuje według reguł wolnego rynku, starając się jednocześnie modyfikować jej prawne ramy na własną korzyść, stanowiąc zbiór graczy mogących przechodzić od jednego do drugiego rynku zazwyczaj istniejącego w ramach organizmów państwowych. Struktura suwerennych państw narodowych, wzmacniając zakres swobody działania globalnych graczy ekonomicznych, jest o wiele bardziej użyteczna dla tych ostatnich niż jakakolwiek mniej lub bardziej gwałtowna i globalna rewolucja polityczna. Tym samym mechanizmy wolnego rynku w ramach struktur konkurujących ze sobą państw narodowych czy ich związków są czynnikami ułatwiającymi, a nie utrudniającymi rozwój cywilizacji informatycznej. Jednocześnie jednak, prawie niezauważalnie, przestają być one nie tylko jedynym, lecz także głównym podmiotem działań politycznych.

12 Zob. B.R. Barber, Dżihad kontra McŚwiat, Warszawa 1997.

${ }^{13}$ S. Vaidhyanathan, The Googlization of Everything (and Why We Should Worry), Berkley 2012. 
Pomimo istnienia w dalszym ciągu tych samych struktur politycznych zmienia się jakby niezauważalnie, bo poza sferą świadomości nawet osobowych aktorów politycznych, ich sposób funkcjonowania. Zmiana mechanizmów i relacji społecznych powoduje przy tym, że w odniesieniu do cywilizacji informatycznej konieczne jest definiowanie na nowo wszelkich kategorii politycznych. Tak jest choćby z rozumieniem władzy politycznej. Teoria rozkazu i posłuszeństwa ma charakter eksplanacyjny w tej cywilizacji jedynie w niektórych instytucjach (zazwyczaj totalnych) oraz nielicznych niewielkich grupach społecznych. We wszystkich innych wypadkach konieczne jest używanie teorii władzy symbolicznej, strukturalnej, proceduralnej, intencjonalnej i pozaintencjonalnej, soft, hard and smart power Josepha S. Nye'a Jra itd. ${ }^{14}$

Podobnie trzeba będzie przetransformować inne kategorie politologiczne. Dotyczy to również typologii reżimów politycznych. Skoro państwo przestaje być głównym podmiotem działań politycznych, to tym samym jego klasyczna Jellinowska definicja zaczyna się rozmywać. Terytorium i ludność przestają być wyróżnikami definicyjnymi państwa, a władztwo publiczne o mniej lub bardziej suwerennym charakterze nie przysługuje wyłącznie państwu. Procesy deterytorializacji oraz wzrostu mnogości przynależności będą musiały objąć także suwerenne struktury polityczne. Jednocześnie muszą się zmieniać również typy reżimów politycznych.

Istnieje dość dużo tekstów politologicznych dotyczących totalitaryzmu w warunkach cywilizacji informatycznej. Pierwszy z nich ${ }^{15}$ wskazuje na ogromne możliwości techniczne pozwalające na śledzenie mas społecznych. Panopticon pozwalał na dokładne śledzenie wszelkich zachowań ludzkich. Wszechobecne telewizory pełniące równocześnie funkcje kamer w Roku 1984 George'a Orwella spełniały podobne zadanie. Dzisiejsze środki techniczne pozwalają na dokładne odwzorowanie nie tylko działań i wszelkich kontaktów społecznych, ale też intencji i zamiarów. Możliwości śledzenia zarówno pod względem masowości, jak i wszechstronności są w świecie cywilizacji informatycznej nieograniczone ${ }^{16}$. Jednakże sama możliwość śledzenia nie jest wystarczająca choćby tylko dla skutecznej kontroli społecznej, będącej przecież podstawowym mechanizmem zapewniającym trwałość każdej grupie społecznej. Konieczne jest jeszcze istnienie skutecznych mechanizmów ekskluzji w przypadku nieprzestrzegania norm obowiązujących $\mathrm{w}$ danej grupie. W wypadku reżimu politycznego muszą zatem istnieć zarówno odpowiednie, mniej lub bardziej wyspecjalizowane, struktury organizacyjne służące zapewnieniu mu trwałości, jak i adekwatny mechanizm

14 Szerzej zob. R. Bäcker, Nietradycyjna teoria polityki, Torun 2011.

15 J. Bentham, Panopticon or the Inspection House, London 1791.

16 Zob. M. Los, Looking into the Future. Surveillance, Globalizaton and the Totalitarian Potential, [w:] Theorizing Surveillance. The Panopticon and Beyond, red. D. Lyon, Routledge 2011; W.D. Perdue, The New Totalitarianism. Cyber-Hegemony and the Global System, [w:] Globality Versus Democracy? The Changing Nature of International Relations, red. H. Köchler, Vienna 2000. 
konformizmu społecznego. Same możliwości śledzenia nie są i nie mogą być czynnikiem przesądzającym o istnieniu danego typu reżimu. Niewątpliwie jednak, jeśli zostaną zintegrowane wszystkie systemy informacyjne, w tym m.in. przepływów płatniczych, monitoringu i ruchu w Internecie ${ }^{17}$, to jego dysponent uzyska potężne narzędzie, o wiele bardziej wydajne niż XX-wieczne totalitarne tajne służby policyjne.

$\mathrm{O}$ wiele bardziej inspirującym tropem jest jednak spostrzeżenie Ulricha Becka wynikające $\mathrm{z}$ obserwacji działań głównych aktorów politycznych globalizacji po 11 września $2001 \mathrm{r}$. Pisał on: „Argument o powszechnym zagrożeniu otwiera bramy przed światowym fundamentalizmem prewencji" ${ }^{18}$. Poczucie globalnego zagrożenia to nic innego jak konsekwencja kreacji braku bezpieczeństwa — jednej z podstawowych potrzeb każdego człowieka. Tym samym uzyskuje się potężne narzędzie z jednej strony do sterowania masowymi zachowaniami ludzkimi, a z drugiej dla zwiększania własnej, i to nie tylko militarnej, potęgi władczej. Jednocześnie możliwe się staje w ramach relacji władczych uzyskanie znaczącej dysproporcji uprawnień imperialnych nad obywatelskimi, a co za tym idzie otwarta powstaje droga do utraty suwerenności przez naród polityczny, złożony przecież w ogromnej większości z jednostek podporządkowanych organom władzy publicznej.

Warto przy tym dodać, że im szerszy i bardziej dotkliwy jest zakres prewencji, tym w większym stopniu staje się on argumentem na rzecz nasilenia postaw anihilacyjnej kontrakulturacji, będącej typową konstrukcją myślową dla antyglobalistycznego terroryzmu. Powstaje błędne koło, z którego nie ma wyjścia - im bardziej walczymy z terroryzmem i mu zapobiegamy, tym większy jest zasięg bazy społecznej traktującej działania terrorystyczne jako uprawnione. Tym samym większe jest zagrożenie terrorystyczne, któremu trzeba zapobiegać. Konieczne jest jednak przy tym uściślenie: dopóki siła grup interesów politycznych związanych z ,przemysłem” walki z terroryzmem jest mniej znacząca od konglomeratu pozostałych grup interesów, dopóty możliwe jest wyjście z tego koła poprzez zmniejszenie zakresu antyterrorystycznej prewencji. Po przekroczeniu tego progu nie ma już rzeczywiście wyjścia z błędnego koła.

Terroryzm jest przy tym zjawiskiem, a nie podmiotem. Walka z terroryzmem staje się zatem możliwa dopiero wtedy, gdy zdefiniujemy podmiot, który uważamy za nosiciela terroryzmu. Możność definiowania tego podmiotu jest tym samym władzą określania wroga zagrażającego wszystkim — staje się on lub może się stać wrogiem obiektywnym. Dla przetrwania narodu lub całej demokratycznej ludzkości konieczne jest jego całkowite zniszczenie. Ponieważ jednak terroryzm jest zjawiskiem, to jego całkowita anihilacja nie jest możliwa. Wojna $\mathrm{z}$ terroryzmem to więc niekończąca się historia. Tymczasem walka $\mathrm{z}$ wrogiem obiektywnym jest podstawowym mechanizmem napędowym struktur totalitarnych.

17 Zob. R. Spears, M. Lea, Panacea or Panopticon? The Hidden Power in Computer-mediated Communication, „Communication Research” 21, 1994, nr 4, s. 427-459.

18 U. Beck, Władza i przeciwwładza w epoce globalnej, Warszawa 2005, s. 360-361. 
Im zacieklejsza jest zatem walka z terroryzmem, tym intensywniej są kreowane organizmy totalitarne. Ta ostatnia zależność dotyczy zresztą wszelkich kategorii wroga obiektywnego lub nimi się stających.

Organizmy te nie muszą mieć jednak charakteru państwowego. Zarówno w okresie międzywojennym, jak i później istniało (i istnieje) w świecie wiele struktur pretotalitarnych, ale również charakterystycznych dla dojrzałego oraz epigońskiego totalitaryzmu. Najczęściej mają one charakter wodzowskich zhierarchizowanych partii typu zakonu. Konieczne jest przy tym zaznaczenie, że nie chodzi o strukturę formalno-prawną, ale spełniającą kryterium definicyjne partii, tzn. dążenie do zdobycia bądź utrzymania władzy publicznej. Tym samym mogą one stanowić stowarzyszenie, klub lub choćby zamkniętą internetową grupę dyskusyjną. W związku z tym ich wyróżnikiem nie może być istnienie aparatu partyjno-państwowego czy masowej i sterowanej mobilizacji mas społecznych.

Struktury totalitarne w ogromnej większości nie miały i nie mają statusu partii rządzącej, choć niewątpliwie najbardziej znane są te, które taki status osiągnęły. Tym samym konieczne jest ich zdefiniowanie w inny sposób niż w wypadku reżimów politycznych. Ich niewątpliwymi esencjonalnymi wyróżnikami będą: gnoza polityczna w rozumieniu Erica Voegelina i Alaina Besançona oraz quasi-charyzmatyczny wódz (niezależnie od tego, czy jest on jeszcze żywy) traktowany jako centralny składnik tożsamości danej grupy. Wtórne znaczenie posiada przy tym istnienie struktury typowej dla partii typu zakonu, tak jak pojmował to Maurice Duverger ${ }^{19}$.

W konsekwencji zasób semantyczny, symbolika czy stosowanie przemocy nie są wyróżnikami mogącymi pozwolić na przyporządkowanie danej struktury do totalitarnej. Niewątpliwie jednak niezhierarchizowane używanie zasobów semantycznych typowych dla ideologii kolektywnych czy religii nieuniwersalnych (pogańskich, etnicznych), eksponowanie symboliki zaczerpniętej z historycznych ruchów faszystowskich, nazistowskich, komunistycznych itd. czy istnienie bojówek są znaczącymi poszlakami mogącymi wskazywać na totalitarny charakter danej organizacji. Jednak spełnienie tylko tych warunków może wskazywać zarówno na charakter totalitarny, jak i fundamentalistyczny danej organizacji. Dla ostatecznego przesądzenia o totalitarnym charakterze badanej struktury konieczne jest zatem istnienie wiarygodnych i znaczących argumentów świadczących (warto to powtórzyć) o dominacji gnozy politycznej, traktowania wodza jako megaantroposa (lub zdolnego do jego kreacji) oraz — w mniejszym stopniu struktury organizacyjnej typowej dla partii zakonu.

Tym samym stosowanie terroru, a nawet bezpośrednia akceptacja jego użycia nie są warunkami konstytuującymi istnienie organizacji totalitarnej. Niewątpliwie jednak organizacje totalitarne posiadają o wiele większą predylekcję do

19 M. Duverger, Political Parties: Their Organization and Activity in the Modern State, London 1959; M. Sobolewski, Partie i systemy partyjne świata kapitalistycznego, Warszawa 1974. 
stosowania przemocy niż struktury społeczeństwa obywatelskiego. Wynika to nie tylko z zanegowania dialogu będącego rezultatem czarnego-białego schematu myślenia. Ten ostatni jest typowy również dla myślenia fundamentalistycznego czy znaczącej części myślenia plemiennego. Bardziej znaczące jest istnienie kategorii wroga obiektywnego (celem musi być jego anihilacja albo przynajmniej ekspulsja) jako centralnej figury gnozy politycznej oraz specyficznej zmilitaryzowanej struktury organizacyjnej. Tak długo jednak, jak użycie przemocy jest przeciwskuteczne (ze względu na groźbę represji ze strony sprawnego państwa) albo osiąganie celów jest możliwe przy pomocy innych środków, nie jest ona zazwyczaj stosowana. Jednocześnie zdecydowana większość organizacji totalitarnych w silnych państwach demokratycznych (ale też autorytarnych) przemocy nie musi stosować i zazwyczaj nie stosuje.

Zjawisko niestosowania przemocy jest tym bardziej typowe, im częściej dostępne są inne sposoby zarówno utrzymania spoistości danej grupy, jak i realizacji najistotniejszych celów danego typu gnozy politycznej. Te możliwości znacząco się poszerzają wraz z rozwojem sieci społecznościowych. Bezkarność kreowania i rozpowszechniania fake news ${ }^{20}$, dowolność stosowania fotomontaży (i to nie tylko przy pomocy Photoshopa) to jedynie przykłady technicznych możliwości stojących przed twórcami mowy nienawiści. Najbardziej skrajną formą tej ostatniej jest dążenie do wykreowania stereotypu wroga obiektywnego w danym momencie ukonkretnionym w osobie lub grupie traktowanej jako jego personifikacja.

Zewnętrzny ogląd tej walki o kreowanie ukonkretnionego stereotypu wroga obiektywnego tworzy obraz karnawałowy. Nieustanne pojawianie się nowych wcieleń medialnych danego wroga ma tworzyć stereotyp zła absolutnego. Te wielobarwne i wielokształtne obrazy jednocześnie wyglądają epigońsko, patosowo-pastiszowo i śmieszno-przerażająco. Jest to swoiste połączenie niezbyt wysokiej jakości horroru zarówno z nieudolnymi postaciami diabła z ludowych procesji okołowielkanocnych, jak i ze średniowiecznymi karnawałowymi szyderstwami. Jednakże tego typu produkcja medialna znajduje akceptację wśród osób myślących czarno-białymi schematami, a więc wierzącymi w posiadanie prawdy, której trzeba bezgranicznie bronić w oblężonej twierdzy przed wszelkimi możliwymi wrogami. Ten rodzaj totalitaryzmu ze względu na jego wizerunek zewnętrzny można nazwać atrakcyjnym, choć dokładniejsze byłoby sformułowanie w języku angielskim: glamour totalitarianism ${ }^{21}$.

20 Zob. A.M. Kaplan, M. Haenlein, Users of the World, unite! The Challenges and Opportunities of Social Media, „Business Horizons” 51, 2010, nr 1, s. 59-68; H. Allcott, M. Gentzkow, Social Media and Fake News in the 2016 Election, „National Bureau of Economic Research Work Paper” 2017, nr 23089.

21 Podobne określenie pojawia się wobec faszyzmu, zarówno w literaturze brytyjskiej, jak i rosyjskiej. Zob. K.L. Morris, Fascism and British Catholic Writers 1924-1939. Part 2, „New Blackfriars" 80, 1999, nr 936, s. 82-95; R. Bäcker, Rosyjskie myślenie polityczne za czasów prezydenta Putina, Torun 2007. 
W istocie kreowanie wizerunku spersonifikowanego wroga obiektywnego w przypadku trwałego i znaczącego zakorzenienia w świadomości społecznej staje się usprawiedliwieniem i zarazem tworzy ramy bezalternatywności decyzyjnej dla stosowania działań mających na celu wyeliminowanie ze świata konkretnych osób bądź grup społecznych zetykietyzowanych jako wróg. Nie musi to być ewaporacja ze świata rzeczywistego. Ekskluzja może dotyczyć świata politycznego lub minimalistycznie kręgu styczności społecznych (minimalistycznie choćby poprzez usunięcie z grona znajomych w sieci społecznościowej). Jest to zależne nie tylko od wielkości horyzontu postrzeganego świata, lecz także od zasięgu stawianych przez daną organizację totalitarną celów.

Cywilizacja informatyczna pozwala przy tym na tworzenie wielu światów na raz. Możliwe jest funkcjonowanie zarówno na rozmaitych poziomach deterytorialnego świata rzeczywistego, jak i w świecie wirtualnym na różnych poziomach pomiędzy awatarem a ujawnianą tożsamością. Tym samym kreowanie więzi społecznych staje się o wiele łatwiejsze i w dodatku w ogromnym stopniu pozbawione moderującego wpływu kontroli społecznej takich grup społecznych, jak rodzina, krąg przyjaciół czy sąsiedzi. Potencjał powstawania dowolnych grup/ zbiorowości społecznych niezwykle się zwiększył.

Zwiększa się również potencjał pola różnorodności gnozy politycznej. Uporządkowany, w miarę stabilny i przewidywalny świat industrialny został zastąpiony płynną nowoczesnością ${ }^{22}$, gdzie nie tylko wszystko się zmienia, lecz także wektory oraz logika tych zmian są raczej niepewne. Tym samym możliwe staje się transformowanie o wiele bardziej różnorodnych sposobów myślenia w totalitarną gnozę polityczną, niż miało to miejsce $\mathrm{w}$ XX w. Kluczowe jest w takim wypadku pytanie, jak odróżnić myślenie typowe dla gnozy politycznej od każdego innego sposobu myślenia? Prócz kategorii wroga obiektywnego konieczne jest wymienienie podmiotu wyobrażonego oraz dążenie do apokatastazy (możności powszechnego, nawet przymusowego zbawienia doczesnego bądź duchowego). W myśleniu bolszewickim kapitaliści i kułacy przeszkadzali światowemu proletariatowi w wyzwoleniu całej ludzkości z ucisku i wyzysku. Naziści wierzyli, że Żydzi są najważniejszą przeszkodą w zapewnieniu rasie aryjskiej powszechnego szczęścia w Tysiącletniej Rzeszy. Jeśli istnieje ten schemat myślenia, możemy mówić o gnozie politycznej. Czy podany poniżej przykład należy do tego schematu? Ci, którzy nie realizują praw człowieka, uniemożliwiają ludzkości osiągnięcie powszechnego stanu demokracji i dobrobytu. Gnoza polityczna może występować zarówno w wariantach językowych typowych dla bolszewizmu i nazizmu, jak i nawet myślenia operującego językiem np. praw człowieka. Nie jest ważny zasób semantyczny, kryterium przesądzającym o kwalifikacji do gnozy politycznej jest schemat myślenia.

Glamour totalitarianism ma rozmaite oblicza. Konieczne jest przy tym zaznaczenie, że rzeczywiste struktury myślenia oraz sposoby organizacji grup

22 Z. Bauman, Plynna nowoczesność, Kraków 2006. 
społecznych sytuują się pomiędzy antynomicznymi typami idealnymi, a niesłychanie rzadko są prawie z nimi zbieżne, nigdy jednak nie będąc z nimi tożsame.

Totalitarne ruchy i sposoby myślenia w społeczeństwach informatycznych są i zapewne będą o wiele bardziej zróżnicowane i o wiele bardziej atrakcyjne niż oparte na żywiole mas i brutalnej sile zmilitaryzowane partie typu zakonu, gwałtownie rozwijające się w ogarniętych kryzysem strukturach industrialnych. W XX w. masy ulegały totalitarnemu ukąszeniu nie tylko ze względu na chęć przetrwania, lecz także dominację wegetatywnych oraz postplemiennych struktur myślenia, będących swoistą otuliną dla totalitarnej gnozy politycznej. W cywilizacji informatycznej substytutem chęci przetrwania może być wszechogarniające poczucie zagrożenia wzmacniające czarno-białą wizję świata, w ramach którego naszą oblężoną twierdzę atakują ze wszystkich stron wrogowie. Do tego fundamentalistycznego myślenia w miarę łatwo można wkomponować kategorię wroga obiektywnego przeszkadzającego podmiotowi wyobrażonemu w realizacji celów apokatastatycznych.

Mało prawdopodobne jest ukształtowanie podległych tylko jednemu typowi gnozy politycznej reżimów totalitarnych na poziomie państw narodowych, a tym bardziej ich ugrupowań. O wiele łatwiej wyobrażalne jest utworzenie chwilowej koalicji rozmaitych ugrupowań totalitarnych i fundamentalistycznych w celu stworzenia szerokiego sojuszu mającego na celu zdobycie władzy państwowej. Jego sprawność będzie jednak zapewne dość niska zarówno ze względu na oddziaływania zewnętrzne globalnych aktorów politycznych i gospodarczych oraz instytucji i działań typowych dla opancerzonej demokracji (militant democracy ${ }^{23}$ ), jak i bardzo duży poziom wewnętrznej niespójności takiej szerokiej koalicji sił niedemokratycznych.

Glamour totalitarianism w społeczeństwie informatycznym jest i zapewne będzie nie tylko w miarę łagodny i atrakcyjny (choć nie oznacza to, że mniej groźny), lecz także bardziej zróżnicowany i jeszcze trudniejszy do zidentyfikowania niż w XX w.

\section{Bibliografia}

Allcott H., Gentzkow M., Social Media and Fake News in the 2016 Election, „National Bureau of Economic Research Work Paper" 2017, nr 23089.

Arendt H., The Origins of Totalitarianism, Orlando-New York-London 1973.

Bäcker R., Nietradycyjna teoria polityki, Torun 2011.

Bäcker R., Rosyjskie myślenie polityczne za czasów prezydenta Putina, Torun 2007.

Barber B.R., Dżihad kontra McŚwiat, Warszawa 1997.

Bauman Z., Ptynna nowoczesność, Kraków 2006.

Beck U., Władza i przeciwwładza w epoce globalnej, Warszawa 2005.

Bentham J., Panopticon or the Inspection House, London 1791.

23 Zob. The Militant Face of Democracy. Liberal Forces for Good, red. A. Geis, H. Müller, N. Schörnig, Cambridge 2013; The „Militant Democracy” Principle in Modern Democracies, red. M. Thiel, Routledge 2016. 
Besançon A., Les origines intellectuelles du léninisme, Calmann-Lévy 1994.

Duverger M., Political Parties: Their Organization and Activity in the Modern State, London 1959. Friedrich C.J., Brzeziński Z.K., Totalitarian Dictatorship, Cambridge 1965.

Jesse E., Totalitarismus im 20. Jahrhundert. Eine Bilanz der internationalen Forschung, Bonn 1996. Kaplan A.M., Haenlein M., Users of the World, unite! The Challenges and Opportunities of Social Media, „Business Horizons” 53, 2010, nr 1.

Kołakowski L., Main Currents of Marxism, Oxford 1978.

Kornat M., Bolszewizm, totalitaryzm, rewolucja. Rosja: poczatki sowietologii i studiów nad systemami totalitarnymi w Polsce (1918-1939), Kraków 2004.

Linz J.J., Totalitarian and Authoritarian Regimes, Reading 1985.

Linz J.J., Totalitarianism and Authoritarianism, [w:] The Handbook of Political Science, red. F.I. Greenstein, N.W. Polsby, t. 3. Macropolitical Theory, Reading 1975.

Los M., Looking into the Future. Surveillance, Globalizaton and the Totalitarian Potential, [w:] Theorizing Surveillance. The Panopticon and Beyond, red. D. Lyon, Routledge 2011.

Morris K.L., Fascism and British Catholic Writers 1924-1939. Part 2, „New Blackfriars” 80, 1999, nr 936.

Perdue W.D., The New Totalitarianism. Cyber-Hegemony and the Global System, [w:] Globality Versus Democracy? The Changing Nature of International Relations, red. H. Köchler, Vienna 2000.

Sobolewski M., Partie i systemy partyjne świata kapitalistycznego, Warszawa 1974.

Spears R., Lea M., Panacea or Panopticon? The Hidden Power in Computer-mediated Communication, „Communication Research” 21, 1994, nr 4.

Sułek A., Przeciwko socjologii oralnej, „Kultura i Społeczeństwo” 31, 1987, nr 4.

The „Militant Democracy” Principle in Modern Democracies, red. M. Thiel, Routledge 2016.

The Militant Face of Democracy. Liberal Forces for Good, red. A. Geis, H. Müller, N. Schörnig, Cambridge 2013.

Vaidhyanathan S., The Googlization of Everything (and Why We Should Worry), Berkley 2012.

Walicki A., Marksizm i skok do królestwa wolności: dzieje komunistycznej utopii, Warszawa 1996.

Zmierczak M., Jan Jakub Rousseau — rzecznik totalitaryzmu czy liberalnej demokracji?, „Czasopismo Prawno-Historyczne" 41, 1989, nr 2.

Zmierczak M., Spory o istote faszyzmu: dzieje i krytyka, Poznań 1988.

Zmierczak M., Własność w ideologii narodowych socjalistów, „Czasopismo Prawno-Historyczne” $56,2004, \mathrm{nr} 2$.

\section{GLAMOUR TOTALITARIANISM IN INFORMATION AGE}

\section{Summary}

The totalitarianism of the information civilisation is, in comparison with the 20th century, much more varied, much more attractive externally and usually less likely to use violence. However, in its essence it does not differ from its predecessor of the industrial era. Its definitional features include political gnosis and the existence of a quasi-charismatic leader as well as, to a lesser extent, the existence of a structure typical of a religious order-like political party.

Keywords: glamour totalitarianism, political gnosis, the information age.

Roman Bäcker

backer@umk.pl

Studia nad Autorytaryzmem i Totalitaryzmem 39, nr 1, 2017

(C) for this edition by CNS 